\title{
Understanding Judicial Delays in Debt Tribunals
}

No. 195

02-May-2017

Prasanth V Regy and Shubho Roy

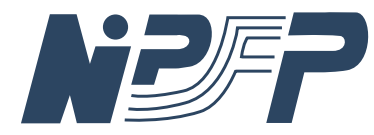

National Institute of Public Finance and Policy New Delhi 


\section{Understanding Judicial Delays in Debt Tribunals}

May 1, 2017

\author{
Prasanth V Regy \\ Shubho Roy \\ National Institute of \\ Public Finance and \\ Policy, New Delhi \\ prasanth.regy@nipfp.org.in \\ shubho.roy@nipfp.org.in
}

We argue that the judicial statistics that are currently collected are inadequate for understanding and solving the problem of judicial delay. We propose a new approach to collecting data, which will lead to useful insights about delays. We apply this approach to a dataset, and find that about half the time taken by cases is lost to delays. Most delays are due to the petitioners asking for more time to file documents. 
NIPFP Working Paper No. 195, April 2017. The views expressed in the paper are those of the authors. No responsibility for them should be attributed to NIPFP.

The authors are thankful to Dr. Renuka Sane, Anirudh Burman, Pratik Datta, Kushagra Priyadarshi and Sanhita Sapatnekar for their contributions to the research project. They would also like to thank Anirudh Burman and Pratik Datta for helpful comments. 


\section{Introduction}

Over the last few decades, economic research has focused on the quality of institutions to explain differences in economic outcomes among nations. The judiciary is one of the three branches of the government of a nation. The functioning of the judiciary has profound consequences for the development of a country. In particular, judicial delays cause harm to the growth and the development of the country.

While there has been research showing that improving functioning of courts has broader economic consequences, there has been little research which can help policy makers on how to improve judicial performance. A key reason for this is that judicial delays are not measured in India. The existing systems only measure the total number of pending cases, or the total amount of time taken by various judicial processes. While these numbers may give an idea of the total time taken for judicial processes, it does not provide any information about delays or about the reasons for the delays. Without scientific evidence there is divergence of opinion about the cause of judicial delays, different branches of the government have diagnosed the cause of delay differently. This impedes clear action on solving the problem.

We posit that any system of measurement which can help in solving the problem of judicial delays has to: first, be able to define judicial delay; identify the cause of the delay; and finally, identify the party which caused the delay. In this paper we propose a novel approach to judicial statistics which can help policymakers identify the cause of judicial delays in India. This, in turn, can create legal and administrative changes driven by concrete and actionable evidence about judicial delays.

Our framework for identifying the causes of judicial delay follows three steps of identification. First, we identify hearings which are failures. Then we identify the party which caused the failure. Finally, we identify the recorded reason for the failure.

Failure of a hearing is defined as when the planned judicial step as per procedural law did not happen on the day of the hearing. To make this determination, we utilised the interim orders of a case. Interim orders are generated each time a case is presented before a judicial officer in a hearing. These interim orders are recorded in the case file of each individual case and kept with the court. While a case will have one final order/judgment determining the dispute, it will have multiple interim orders which reflect all the proceedings which constitute a case. Therefore, interim orders can be considered as the constituents of a case. Each 
order records what happened in each hearing of the case as it proceeds towards the final order. Based on this analysis, we define judicial delay due to a failed hearing as the time between the failed hearing and the next time the case was presented for hearing. Total judicial delay in a particular case can be calculated by summing up the delays caused by all the failed hearings in that case. We believe that this system provides a scientific and value neutral method of establishing judicial delay.

After identifying hearings which were failures, we identify the party causing the delay. A judicial process is a tripartite process comprising of the plaintiff, defendant and the judicial officer. If the plaintiff was expected to produce a document to prove something and is unable to do it in time, the delay can be attributed to the plaintiff and not the judiciary. If the judicial officer goes on leave and the court does not work on a given day, the delay can be ascribed to the judicial officer.

Most interim orders record the 'reason for delay'. We find that the reasons recorded in the orders can be classified into some standard categories.

Using this framework, we study 22 cases of the Debt Recovery Tribunal (DRT) III of Delhi, which had a total of 474 orders between them. Analysing these orders, we find that as many as half of the hearings result in failures. Contrary to commonly held notions, the majority of delays are caused by the petitioner. We also find that the lawyers and the tribunal itself cause a significant part of the delay.

The majority of delays are because of requests from the parties for more time to submit documents. Other common reasons include the absence of the lawyers or of tribunal officers. We also find that the judicial delays may not be the result of high workload of Indian courts but the cause of the high workload.

Our method of study highlights the need for evidence based reforms in tackling the problem of judicial delays. Based on our findings, we indicate some policy and legal changes which can be used to tackle this problem.

The rest of this paper is organised as follows. Section 2 discusses why judicial delays are a problem, and highlights the persistence of the problem in India. Section 3 relates the persistence of the problem to the measurement of judicial delays. In section 4, we present our approach to measuring these delays, and section 5 presents the results of applying this methodology to data from the DRT. We discuss the results in Section 6, and section 7 concludes. 


\section{The problem of judicial delays}

The problem of judicial delays in India has been a persistent one. As shown in Table 1, the premier law reform body of the country seems to be repeating the same concerns about a slow judiciary over a period of 36 years. Even when it made the first statement in 1978, it was "not a recent phenomenon", but one which had already assumed "gigantic proportions".

Table 1: Judicial delays, a persistent problem.

\begin{tabular}{ll}
\hline Law Commission, $\mathbf{1 9 7 8}$ & Law Commission, 2014 \\
\hline $\begin{array}{l}\text { The problem of delay in the disposal of } \\
\text { cases pending in law Courts is not a recent }\end{array}$ timely justice because of huge backlog of \\
phenomenon. It has been with us since a & cases for which the current judge strength \\
long time. A number of Commissions and & is completely inadequate. Further, in ad- \\
Committees have dealt with the problem, & dition to the already backlogged cases, the \\
and given their reports. ... [T]he problem & system is not being able to keep pace with \\
has persisted. Of late, it has assumed gi- & the new cases being instituted, and is not \\
gantic proportions. This has subjected our & being able to dispose of a comparable num- \\
judicial system, as it must, to severe strain. & ber of cases. The already severe problem of \\
It has also shaken in some measure the con- & backlogs is, therefore, getting exacerbated \\
fidence of the people in the capacity of the & by the day, leading to a dilution of the Con- \\
Courts to redress their grievances and to & stitutional guarantee of access to timely \\
grant adequate and timely relief. & justice and erosion of the rule of law.
\end{tabular}

There are many ways in which the poor functioning of the judiciary can harm a country. Hay and Shleifer explore the reasons why East European countries grew faster than Russia after the collapse of the Soviet Union. ${ }^{1}$ They posit that East European countries were able to implement institutional reforms better than Russia. One key institution they looked at was courts and their efficiency. The authors note that public methods of dispute resolution, i.e. using courts have higher benefits in an emerging economy. They argue that:

... in an emerging economy the coordination benefits of public rules

\footnotetext{
${ }^{1}$ See, Jonathan R. Hay and Andrei Shleifer. "Private Enforcement of Public Laws: A Theory of Legal Reform”. In: The American Economic Review 88.2 (May 1998): Papers and Proceedings of the Hundred and Tenth Annual Meeting of the American Economic Association, pp. 398-403.
} 
may be enormous.

One effect which has been well studied is the harm these delays do to contracts. When parties know that contracts will not be enforced by courts, or will be enforced after long delays, there is a strong incentive to breach contracts with impunity. As Hobbes said: ${ }^{2}$

"... he that performeth first has no assurance the other will perform after, because the bonds of words are too weak to bridle men's ambition, avarice, anger, and other passions, without the fear of some coercive power..."

Another consequence is that in the presence of judicial delay, parties refrain from entering into contracts unless they have other means to enforce them, such as social pressure. This leads to lost opportunities for carrying out economically productive activities. Bianco, Jappelli, and Pagano show that improvements in judicial efficiency in judicial districts of Italy increased the amount of financial activity. ${ }^{3}$ Chemin studied the effect of changes in procedural law in India on the economy. The author found that certain amendments to the main law governing court procedure, the Civil Procedure Code, had an effect of slightly speeding up court processes. In turn this led to a decrease in the likelihood of breach of contract, and an increase in investment as well as in access to credit markets. ${ }^{4}$ Burkart, Panunzi, and Shleifer argue that the concentration of family owned firms in developing countries is a function of lower levels of investor protection. ${ }^{5}$ This may explain why, in India, many firms are family firms: they are able to use non-legal enforcement mechanisms.

The political and social consequences of an inefficient judiciary are less easy to quantify, but they are probably far more significant. Fundamental rights like the right to life and liberty, the right to freedom of speech, or the right to equality may not be enforced because of court delays. Citizens lose faith in the rule of law and in the capacity of the state to act in their interest.

\footnotetext{
${ }^{2}$ Chapter XIV, paragraph 18 of Thomas Hobbes. Of Man, Being the First Part of Leviathan. The Harvard Classics. Bartleby.com, 2001.

${ }^{3}$ Magda Bianco, Tullio Jappelli, and Marco Pagano. Courts and Banks: Effects of Judicial Enforcement on Credit Markets. CSEF Working Papers 58. Centre for Studies in Economics and Finance (CSEF), University of Naples, Italy, June 2001.

${ }^{4}$ Matthieu Chemin. "Does Court Speed Shape Economic Activity? Evidence from a Court Reform in India”. In: Journal of Law, Economics, and Organization 28.3 (2012), pp. 460-485.

${ }^{5}$ Mike Burkart, Fausto Panunzi, and Andrei Shleifer. "Family Firms". In: The fournal of Finance 58.5 (Oct. 2003), pp. 2167-2201.
} 
Table 2: How the Supreme Court measures pendency

\begin{tabular}{cccc}
\hline Pendency & Institution & Disposal & Pendency \\
As on 31.12.2015 & $\begin{array}{c}01.01 .2016- \\
30.09 .2016\end{array}$ & $\begin{array}{c}01.01 .2016- \\
30.09 .2016\end{array}$ & As on 30.09.2016 \\
\hline 59,272 & 59,386 & 57,720 & 60,938 \\
\hline
\end{tabular}

Source: Table VII, Institution, Disposal, and Pendency of Cases in the Supreme Court (01.01.2016 to 30.09.2016): Cumulative Statistics of the Indian fudiciary: Annual Report 2015-2016

\section{Solving the problem}

\subsection{A problem of measurement}

Judicial delays are not measured in India. Judicial statistics in India only measures stock and the flow of cases at the end of each year. Judicial statistics focus heavily on pendency (i.e., pending cases), which is calculated by adding up cases at the beginning of the year with the new cases instituted in the year and subtracting the cases finished during the year. As an illustration, table 2 is a reproduction of the way the Supreme Court reports statistics about judicial work. ${ }^{6}$ Most other courts in India which track judicial work use the same method for reporting judicial work.

Recently, some courts have started reporting age-wise data on cases. Such information is available for the High Courts and the subordinate courts. For example, Allahabad High Court had 309,634 cases more than 10 years old. ${ }^{7}$ While this may give a good idea of the workload of the judiciary, it does not provide any information about the reason for delays.

The World Bank's Ease of Doing Business Report 2016 measures contract enforcement (and thus, indirectly, the performance of the courts) using a different approach. It conducts opinion surveys by sending questionnaires to local litigation lawyers and judges. It also claims to study the procedural law, but it appears that it is used only to identify the steps in a judicial proceeding. ${ }^{8}$ This approach is useful in enabling a relative evaluation of the India in comparison to other countries, but it is of limited help in understanding the reason for the delays.

\footnotetext{
${ }^{6}$ The Supreme Court has a two step process: admitting, i.e. agreeing to hear the case, and then actually hearing the case. The table provides the total.

${ }^{7}$ Supreme Court of India. Indian Judiciary: Annual Report 2015-2016. 2016, at p.116.

${ }^{8}$ World Bank. Ease of Doing Business Report 2016. Enforcing Contracts Methodology. 2016.
} 
In contrast to these approaches, our analysis is based on granular data about court proceedings. Our preliminary results were published previously. ${ }^{9}$ A recent paper by Khaitan, Seetharam, and Chandrashekaran has also taken a similar approach. ${ }^{10}$

\subsection{What is wrong with the current approaches?}

The approaches mentioned above suffer from three deficiencies, which prevent them from providing meaningful insights into judicial delays. First, there is no clear definition of what constitutes delay. Measurement of pendency may reveal shocking numbers, but it is not clear how we can determine that a particular figure for pendency is 'bad'. Similarly, the approach adopted by the Ease of Doing Business Report enables comparison with other countries, but it cannot answer the question of how much of the time taken for contract enforcement is delay.

Second, the statistical information collected/reported by the courts are not useful in identifying the causes of delay. So we do not know what delay was caused due to the litigants asking for adjournments, the lawyers being absent, or the court administration being slow.

The third issue is that the present system of measurement of judicial delays ignores the fact that there are multiple parties to every judicial proceeding: the plaintiff, the defendant and the judge. Any of the three parties may cause delays, and concentrating only on the judicial officer alone may not be helpful.

\subsection{Diverging diagnoses}

Without scientific research to inform public policy, the consequence has been that there is no clear diagnosis of the reason for judicial delays. Even within the government, there are several opinions among the various wings (judiciary, executive and legislature) about the cause for judicial delay.

The judiciary sees this problem mainly as a result of lack of adequate number of judges. The Resolutions Adopted in the Chief Justices' Conference, 2016 identifies the need to fill up vacant positions in lower judiciary and the High Courts. The

\footnotetext{
${ }^{9}$ Prasanth Regy, Shubho Roy, and Renuka Sane. "Understanding judicial delays in India: Evidence from Debt Recovery Tribunals”. In: Ajay Shah’s Blog (May 16, 2016).

${ }^{10}$ Nitika Khaitan, Shalini Seetharam, and Sumathi Chandrashekaran. Inefficiency and Judicial Delay. New Insights from the Delhi High Court. Vidhi Centre for Legal Policy, 2017.
} 
Chief Justice of India stated that the nation needs 70,000 more judges to solve the problem. ${ }^{11}$

The executive identifies the following causes for the problem: excessive litigation and appeals by the government, re-engineering procedures, need for more judges and trained support staff, lack of use of technology. ${ }^{12}$ A study for the government pointed out that judges in Australia dispose double the number of cases per year, compared to judges in Delhi. ${ }^{13}$

The legislature has favoured the creation of alternate mechanisms (such as Tribunals and Lok Adalats) that minimise procedural formalism. Procedural formalism is the theory that the functioning of courts (thereby efficiency) is determined by the laws which govern the courts: procedural law. It has been contended that procedural formalism can lead to longer duration of dispute resolution and does not improve justice. ${ }^{14}$ This approach of the legislature is evinced from language found in almost all laws which have set up tribunals: ${ }^{15}$

The Tribunal and the Appellate Tribunal shall not be bound the procedure laid down by the Code of Civil Procedure, 1908 (5 of 1908), but shall be guided by the principles of natural justice,...

Without a clear diagnosis of the cause of judicial delay, public policy falls back to treating the symptoms of the problem: that a lot of cases are pending (the pendency measurement approach of Indian courts) or that cases take a long time to be resolved (the Ease of Doing Business Report 2016 approach). An example of this can be found in the resolutions adopted at the last Chief Justices Judicial Conference. It was resolved that courts should give top priority to cases which are more than five years old. ${ }^{16}$ The judiciary is trying to solve the problem that has already arisen. However, there is no discussion or proposed actions for preventing this problem from arising in the future.

\footnotetext{
${ }^{11}$ Binita Jaiswal. "India needs more than 70,000 judges to clear pending cases". In: The Times of India (May 8, 2016).

${ }^{12}$ The National Mission for Delivery of Justice and Legal Reform. Towards Timely Delivery of Fustice to All: A Blueprint for Judicial Reforms. Sept. 2009, is a special government scheme to speed up judicial work, the scheme identifies these as the areas of concern.

${ }^{13}$ See India Development Foundation. Judicial Impact Assessment: An Approach Paper. May 2008, at pp 49-50.

${ }^{14}$ See Simeon Djankov et al. "Courts”. In: The Quarterly fournal of Economics 118.2 (May 2003), pp. 453-517, at pg 456.

${ }^{15}$ See Section 22, "RDDBFI Act". Similar provisions are found in the other legislations governing specialised tribunals as well.

${ }^{16}$ See, resolution 8 of the Resolutions Adopted in the Chief Justices' Conference, 2016. Apr. 23, 2016.
} 


\section{Methodology}

In this section, we describe our methodology and our dataset. We have taken an empirical approach based on granular data for determining the reasons for delays. We find that this approach is very productive, and analysis of the data has revealed many important findings.

We approach the issue of measurement of judicial performance from the point of view of diagnosing and suggesting solutions to the problems contributing to such delay. We contend that in order to be useful in diagnosing and solving the problem of judicial delay, a framework for measurement should:

1. Define delays clearly in an objective and rigorous manner;

2. Identify the causes of the delay.

3. Apportion blame for the delay among the parties to the case.

Our hypothesis was: studying a few court cases in detail will provide a better understanding of the reasons of judicial delay and ways to reduce the delay. So we collected highly granular data for a few cases rather than macro-level statistics for all cases. For each of those few cases, we asked these questions: what happened in that case? By how long was that case delayed? Why was there delay in that case? Who caused the delay in that case?

In this section, we describe how we gathered the answers to these questions for a number of DRT cases. But first we describe why we selected DRTs for this work, and how we define failure and delay.

\subsection{Debt Recovery Tribunals}

For our study we selected the proceedings in the DRT III at New Delhi. DRTs were set up in 1994 "...for expeditious adjudication and recovery of debts due to banks and financial institutions." ${ }^{17}$ We decided to use a DRT for our study for the following reasons:

Location We proposed to go into details of individual cases. This required a number of researchers to visit the court on a daily bases. So we chose a court near our place of work, New Delhi.

Standardisation Normal courts deal with many different types of cases. They can be broadly divided into civil and criminal cases, but the judicial processes are far more varied and depend on the exact legislation under which

\footnotetext{
${ }^{17}$ See the Statement of Objects and Reasons, "Recovery of Debts Due to Banks and Financial Institutions Act”. In: Text of Central Acts 51 of 1993 (1993), pp. 299-312.
} 
the dispute is adjudged. Since we proposed to map the cases to the procedural law, tribunals were attractive. This is because tribunals in India are specialised courts dealing with a few laws. At the time the data was collected, DRTs dealt with only two laws: the Recovery of Debts Due to Banks and Financial Institutions Act, 1993 (RDDBFI), and the Securitisation and Reconstruction of Financial Assets and Enforcement of Security Interest Act, 2002 (SARFAESI). ${ }^{18}$ The procedural law for both types of cases is the same: "Debts Recovery Tribunal (Procedure) Rules, 1993". This simplifies both the types of cases and the procedural laws which applied to them.

Delays The problem of judicial delays in DRTs is well recognised. ${ }^{19}$ In 1990 there were 1.5 million cases filed by public sector banks to recover ₹56.22 billion. ${ }^{20}$ In spite of setting up the DRTs, the number had risen to ₹500 billion by $2016 .{ }^{21}$ Studying judicial processes in DRTs would provide us with insight into the causes of judicial delay.

In a DRT, the cases are generally of these three types:

Original Application (OA): These are cases under the "RDDBFI Act" where the lender files a case against the borrower to recover money. If the tribunal finds in favour of the lender, it passes a final order directing the borrower to pay the amount. These proceedings happen before the Presiding Officer (PO) of the Tribunal.

SARFAESI Application (SA): These are cases under the "SARFAESI Act". This law allows institutional lenders to sell mortgaged assets after giving a notice to the borrower. It is unique in the Indian legal system where the lender does not have to get a court order to enforce his security interest. In these types of cases, usually, the borrower approaches the tribunal trying to restrain the lender from auctioning his/her mortgaged property. These proceedings also happen before the PO.

Recovery Certificate (RC): These are a sub-set of cases under "RDDBFI Act" and usually follows from the OA cases. These cases are similar to enforcement or execution proceedings. After winning an OA case, if the borrower has still not paid the lender, the lender may approach the court to execute

\footnotetext{
${ }^{18}$ Later, the Insolvency and Bankruptcy Code designated them as the Adjudicating Authority for individual insolvency resolution.

${ }^{19}$ Mukund P. Unny. A Study on the Effectiveness of Remedies Available For Banks in a Debt Recovery Tribunal: A Case Study on Ernakulam DRT. CPPR Working Papers. Feb. 2011; Remya Nair. "Debt recovery tribunals' overhaul on the cards to tackle pendency". In: Live Mint (Dec. 24, 2015).

${ }^{20}$ The Statement of Objects and Reasons of the "RDDBFI Act".

${ }^{21}$ Sayan Ghosh. "Debt recovery tribunals fail to clear cases on time; outstanding debts stand at Rs 4,50,000 crore”. In: The Financial Express (May 17, 2016).
} 
the RC issued by the PO. This involves the sale of mortgaged properties or even other properties of the borrower. These proceedings are held before a special court officer called the Recovery Officer (RO) who acts in a quasijudicial capacity. The $\mathrm{RO}$ is responsible for ensuring that the properties of the borrower are identified and sold in a fair manner.

Apart from the officials mentioned above, another important official of the tribunal is the Registrar. This official assists the PO in the administration of the tribunal. The Registrar is responsible for ensuring the completeness of filings prior to listing a case before the PO.

\subsection{Failed hearings and delay}

As we have mentioned earlier, most official statistics do not define or track delay. The Malimath Committee suggested that a dividing line be drawn at two years: cases longer than that would be considered arrears, and should be disposed through a special scheme. ${ }^{22}$ However, this number seems to be arbitrary. A complex case may reasonably take longer than two years, and these should not necessarily be considered delayed. On the other hand, consider a trivial case which can be disposed of within a week, but took a year. It ought to be considered delayed, but it would not be considered a delay by this criterion.

In general, this problem exists whenever we choose any particular duration as the criterion for which case is delayed. Here, we differ from other work in this area. We propose a new definition for delays that is based on whether judicial progress was made in a case or not.

Once a case is admitted in a DRT, it goes through several hearings. We classified the hearings as failures if they met all three of these conditions:

1. The hearing resulted in an adjournment without transacting judicial business;

2. The adjournment was avoidable; and

3. The adjournment was not penalised.

For instance, adjournment due to bomb blasts was not considered a failure. Adjournment due to lawyers being absent were considered failures if no penalty was imposed.

We define delay as the time that elapsed between a failed hearing and the next hearing in that case. This avoids the problem of using an arbitrary duration as a

\footnotetext{
${ }^{22}$ Ministry of Home Affairs. Committee on Reforms of the Criminal Justice System. 2003.
} 
norm for determining delay. This definition may not be useful in all jurisdictions, but it serves the purpose well in situations such as India's, where most delays are due to adjournments.

\subsection{Collecting Data}

Court and tribunal proceedings in India are recorded in "case files". A case file is a complete record of the case, kept in the registry of the court or tribunal. The case file provides a step by step account of the case, recording the proceedings on each date the case came up for hearing before the judicial officer.

A case file usually has copies of the following documents:

1. The application of the plaintiff which started the case.

2. All the interim orders of the court, starting with the order allowing the plaintiff to issue a notice to the defendant. ${ }^{23}$ Each interim order usually states the proceedings that were held on the date of the order and the proposed next date of hearing the case.

3. Any response filed by the defendant, including the preliminary response called the "Written Submission (WS)"

4. All interim applications filed by the defendant or plaintiffs. ${ }^{24}$

5. All notices issued by all the parties.

6. The final judgment of the case.

We got approvals to study the case files of the DRT-III, Delhi, from $11^{\text {th }}$ to $21^{\text {st }}$ of April 2014. The research team spent the first week understanding the processes followed in the DRT and interviewing the officers of the DRT: the PO, the registrar, and RO. The team spent the second week reading the case files of 22 decided cases of the DRT. It went through each hearing and each interim order for all the cases. This has given us granular data about a total of 474 interim orders over these 22 cases.

\subsection{The collected information}

We studied each case file, and recorded information about:

\footnotetext{
${ }^{23}$ This is usually the formal legal notice alerting the defendant that a judicial proceeding has been initiated against him and the court has found valid grounds to require the defendant to present his case.

${ }^{24}$ Interim applications are applications for temporary orders pending the final judgment deciding the case. For example, the creditor may ask the court to restrain the borrower from selling any mortgaged property.
} 
1. The case name;

2. The type of the case: OA, SA, or RC (these types are described in section 4.1);

3. The parties including who filed the case, the lender or the borrower;

4. Date of filing;

5. Date of final order;

6. Decision of the tribunal, which was standardised into: dismissed (withdrawn or otherwise), disposed, closed (as fully satisfied or with liberty to revive later);

7. Date for each hearing of the case;

8. Brief subject for the hearing;

9. Next date of hearing;

10. If the hearing was a failure (as per the criteria mentioned in section 4.2), then which party was responsible for it; and

11. If the hearing was a failure, a standardised reason for failure.

Using the criteria in section 4.2 , we determined that of the 474 orders about which information was collected, 274 were failures.

\section{Results}

\subsection{Delays}

Our study shows that each failure delays the case by about 40 more calendar days.

The cases we examined went on for about 2.7 years on average. This aggregate conceals a lot of variance - the duration varied from as few as 5 months to as many as seven and a half years (Figure 1).

How much of this was necessary? In other words, if the system had functioned well, how much delay could have been avoided? It turns out that of these 474 hearings, 274 hearings (about 58\%) were failures. These failures accounted for more than half the time taken by the cases. So, to a first approximation, we could reduce the duration of the average case by half if we were able to avoid trial failures. But that is not all - if there were fewer trial failures, cases would finish sooner, freeing up slots on the judicial dockets. This would let the remaining cases have more frequent hearings. So the delay would decrease by more than half if these failures were avoided. 
Figure 1: Histogram of case durations.

Duration varies from five months to eight years.

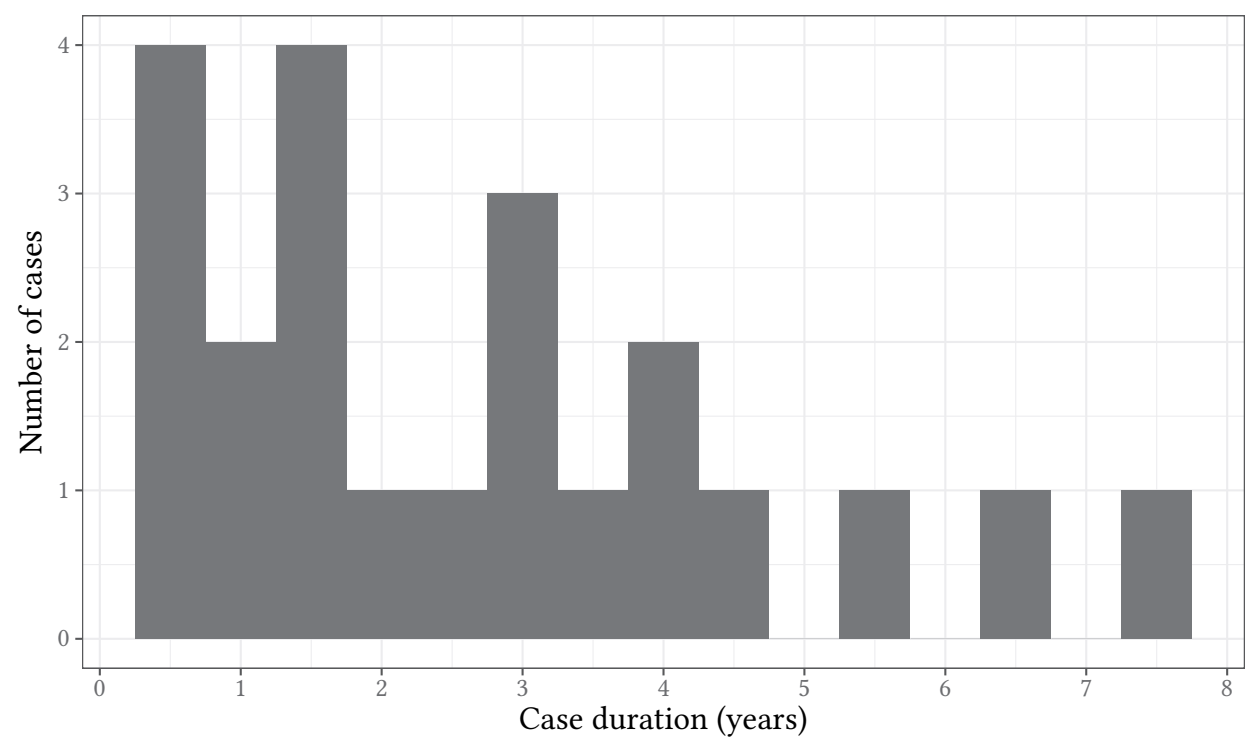

\subsection{Who causes delays?}

The failed hearings can be caused by one or more of three parties: the plaintiff, the defendant, and the tribunal itself. In general, one would expect that the borrower would have an incentive to extend the case - it already has the use of the money, and it would like some time to repay. This expectation is borne out by the data. Looking at the cases filed by the borrower, adjournments due to the borrower-plaintiff account for $46 \%$ of the total time lost, while about $21 \%$ is lost due to the lender, and about $16 \%$ due to the tribunal (see Figure 2).

Now consider the cases filed by the lender. In these cases, one would expect that the lender-plaintiff would want a quick disposal of the case. After all, it has lent the money, and would presumably like it back as soon as possible.

Interestingly, in these cases, it turns out that the largest reason for delays is the plaintiff. The lender-plaintiff accounts for $40 \%$ of the delay, compared to $21 \%$ caused by the defendant and $26 \%$ by the tribunal (Figure 3 ). Many of these delays are because the lender asks for adjournments while it locates and files documents. This violates our expectation that the lender would want his money back quickly.

These lenders are sophisticated financial institutions that, we expect, maintain complete documentation of their debts. They have lawyers on retainer, and have standard processes in place to deal with defaults. Given all this, it is not clear 
Figure 2: Breakup of delays for the cases filed by the borrower.

Predictably, the borrower-plaintiff accounts for most of the delay.

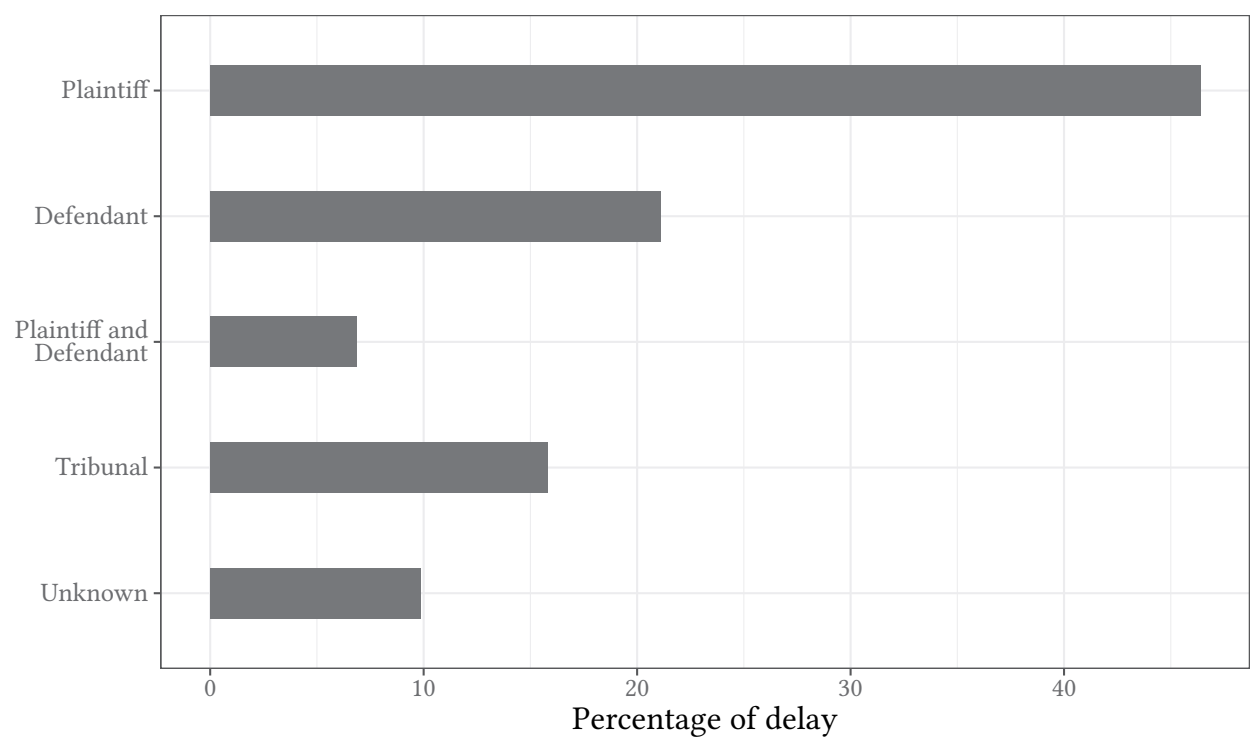

Figure 3: Breakup of delays for the cases filed by the lender.

Surprisingly, the lender-plaintiff accounts for most of the delays!

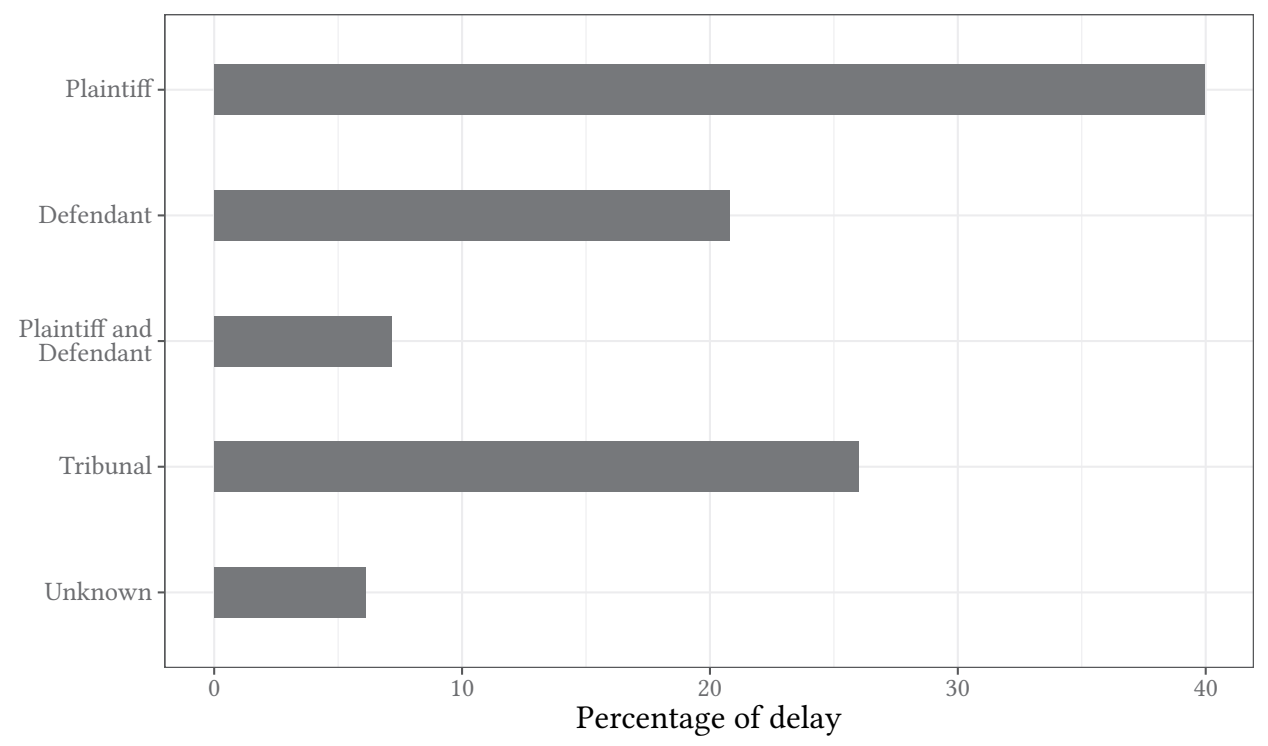

why they would take such a long time to perform tasks that lie well within their control. 


\subsection{Why are delays caused?}

We examined the stated reasons for the failure of the hearing (see Figure 4).

Figure 4: Why do hearings fail?

The major reason is that parties ask for more time to file documents.

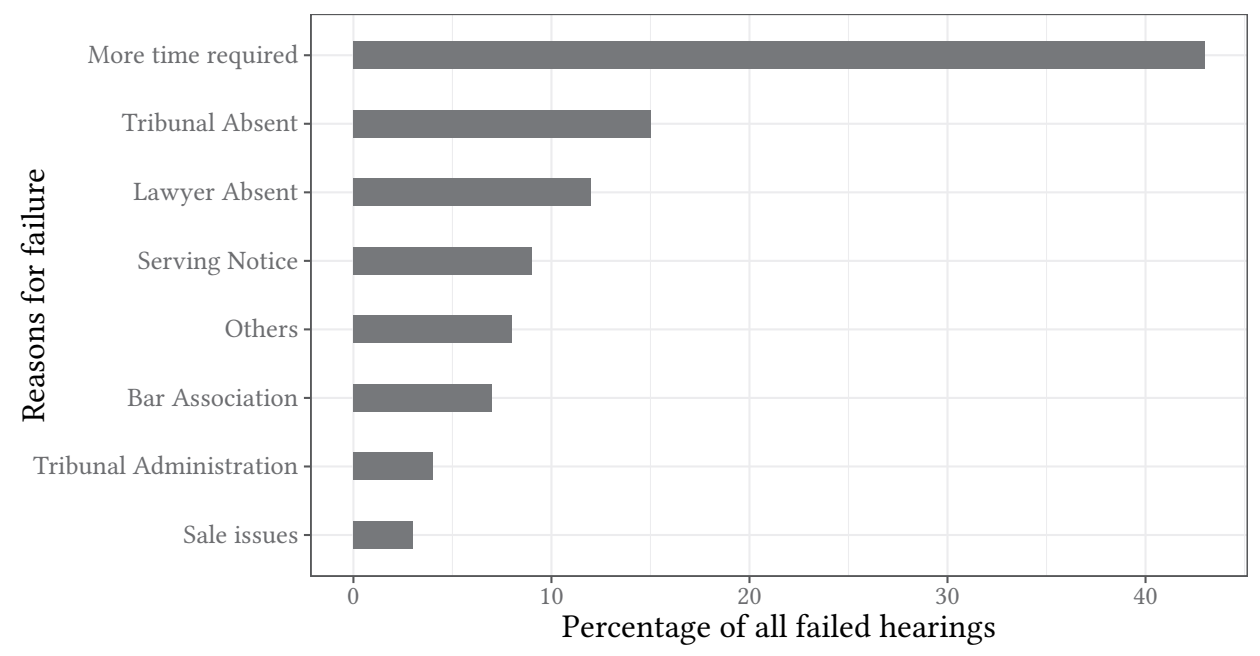

This analysis reveals that $43 \%$ of the adjournments are because of requests by the lawyers for more time, so that they can submit documents or seek client instructions. This is by far the largest reason for seeking adjournments. About 15\% of the adjournments are due to the absence of the PO or the RO of the tribunal. An almost equal amount of delay $(12 \%)$ is due to the absence of one (sometimes, both) of the lawyers. Service of notice and conducting sale together account for about $12 \%$. An interesting category of delay is the one caused by the Bar Associations: about $7 \%$ of the time, the Bar Association calls for holidays (usually for Bar elections, festivals, etc.), and the tribunal obliges.

Consider the single largest reason for these requests for adjournments: more time required for submitting documents. In the vast majority of cases, the documents ought to be easily available, given that the creditors are financial institutions. This suggests that the request for adjournment could have been avoided, had the parties wished to. In this sense, these delays are deliberate. In Table 3, we consider the breakup of this type of adjournment, by the party requesting the adjournment. We can see that in each type of case, it is the plaintiffs who cause this type of delay more frequently. 
Table 3: Percentage of 'More time required' requests, by party and case type. Plaintiffs cause more delay in each case.

\begin{tabular}{lrrr}
\hline Party & OA & RC & SA \\
\hline Defendant & 25 & 34 & 38 \\
Plaintiff & 75 & 66 & 62 \\
Total & 100 & 100 & 100 \\
\hline
\end{tabular}

Another factor that could affect delay is the nature of the lender. In our sample, all the lenders are banks. Some of these banks are private banks and the others Public Sector Banks (PSBs). ${ }^{25}$ An independent-samples t-test was conducted to compare 'Lawyer Absent' and 'More time required' failures caused by banks. There were significantly fewer of these failures per case in the case of private banks $(M=2, S D=.5)$ as compared to PSBs $(M=5.5, S D=1.32), t(14.8)=$ $2.96, p=.01$. Thus, the time lost in these adjournments is much greater if the lender is a PSB than if it is a private bank.

\section{Discussion}

In this section, we discuss some questions that arise in the light of the information presented above in Section 5. Our discussion is based on the idea that those asking for repeated adjournments are imposing a cost on the judiciary and on all its users. Judicial time and capacity are scarce public resources, and procedural delays represent a waste of these resources.

\subsection{Incentives of the parties}

We have seen above (Sections 5.2 and 5.3) that most adjournments are because plaintiffs (especially lenders) request more time to submit documents. Why do lenders file cases in courts, and then ask for so many adjournments? One possibility is that their objective in filing the case is not to obtain a judicial mandate in their favour, but to exert pressure on the borrower to come to a negotiated settlement. This behaviour imposes a cost on the judiciary and on the public.

It also appears (see section 5.3) that there are systematic differences between public and private sector banks with regards to their ability to produce documents

\footnotetext{
${ }^{25}$ PSBs are banks that are majority-owned by the government. They account for about $70 \%$ of the deposits and $66 \%$ of the bank credit in India (Reserve Bank of India. Quarterly Statistics on Deposits and Credit of Scheduled Commercial Banks: December 2016. 2017).
} 
on time and to ensure that their lawyers appear in court. Perhaps the business processes involved in storing and retrieving documents, and the design of incentive structures within PSBs and private banks, are different. It is likely that poor processes in lenders is only a reflection of the processes in the tribunals. If the lenders are confident of getting as many adjournments as they desire, they have no incentive to be respectful of the tribunal's time.

\subsection{Incentives of the lawyers}

Figure 4 indicates that about $12 \%$ of the time, the delay was because of the absence of the lawyers. The many instances where one or the other (often both) lawyers are absent, or both lawyers request adjournments, suggests the possibility that some lawyers may be in no hurry to finish the case. If the incentives of the lawyers are perverse - for instance, if they get paid not on the basis of prompt resolution of the case in favour of their client, but on the basis of the number of hearings - then it is reasonable to expect that they would prefer to have more hearings.

\subsection{Culture of the judicial system}

One of the most striking aspects of the DRTs is the forbearance of the tribunal when dealing with repeated adjournments. Whether it is parties asking for more time to file documents that they ought to have easy access to, or requests by the Bar Association for holidays, or outright absences by lawyers, the POs seem to be very obliging. This points to a general culture in which such seemingly unprofessional behaviour is tolerated in DRTs. In spite of the significant negative externalities created by such behaviour, we see very little evidence of the tribunal acting to dis-incentivise such behaviour, for instance, by imposing penalties on the parties for causing delays.

\subsection{Judicial Processes}

The single largest reason for adjournments (43\%, see Figure 4) was that more time was required to file documents. Some of these proceedings were before the Registrar, and others before the PO. An additional $4 \%$ of the adjournments were due to issues with tribunal administration. Together, these two account for almost half of all the adjournments. 
The Registrar of the tribunal is supposed to ensure that all the requisite documents have been filed before the case goes to the PO. The literature suggests that the Registrar is a point of delay: cases are stuck there for several months before they are listed before the PO. ${ }^{26}$ Part of the reason this process takes so long is that the parties repeatedly request the Registrar for adjournments while they file the documents.

It is not clear why the Registrar tolerates such delays. If the hearings were delayed repeatedly due to this reason, the party could have been penalised for the violation of the tribunal's deadlines. If the plaintiff keeps delaying the submission of essential documents, the case could have been dismissed for the lack of intent to prosecute.

Often, the 'more time to file documents' adjournments happen before the PO. These cases were clearly not ready for more hearings till the documents were filed. The tribunal's time should not be taken up unless the case requires, and is ready for, the application of judicial mind.

This points out an issue with the efficiency of the processes in the tribunal. One possible solution to this problem of inefficient processes is to entrust the processes to an agency that specialises in redesigning, implementing, and administering judicial processes. This is the process followed in most common-law countries, including UK, USA, Canada, and Australia.

\subsection{Tribunal capacity}

Figure 4 shows that about a fifth of the adjournments are attributable to the tribunal administration or due to the absence of tribunal officers. In other organisations (such as hospitals, railway stations, airports, hotels, or customer-facing private offices), when a key employee is absent, alternate arrangements are made so that customer work is not held up. Why are similar arrangements not possible in DRTs?

A possible reason is that POs are overloaded, and there is no extra capacity available to be used in the case of absences. ${ }^{27}$ One solution for this is to increase the number of POs.

\footnotetext{
${ }^{26}$ Unny, A Study on the Effectiveness of Remedies Available For Banks in a Debt Recovery Tribunal: A Case Study on Ernakulam DRT.

${ }^{27}$ An example we saw during data collection: Delhi has three DRTs, but one DRT did not have any PO for months. The PO for one of the DRTs would sit in as the PO for the other DRT too.
} 


\section{Conclusion}

In this paper, we have suggested a new method for understanding judicial delays. We believe that such a rigorous study of the judicial process using fine-grained data will help to obtain new and useful insights about judicial delay. We believe that this can provide the basis for a more informed debate about this problem and the possible solutions to it. Such investigations hold out the promise that a procedural redesign of the conduct of court cases could help reduce delays. Any reform would need to be informed by a sophisticated understanding of the value and the cost of judicial delays, as well as by the principles of economics and public administration.

\section{References}

Bianco, Magda, Tullio Jappelli, and Marco Pagano. Courts and Banks: Effects of Fudicial Enforcement on Credit Markets. CSEF Working Papers 58. Centre for Studies in Economics and Finance (CSEF), University of Naples, Italy, June 2001.

Burkart, Mike, Fausto Panunzi, and Andrei Shleifer. "Family Firms". In: The fournal of Finance 58.5 (Oct. 2003), pp. 2167-2201.

Chemin, Matthieu. "Does Court Speed Shape Economic Activity? Evidence from a Court Reform in India”. In: Journal of Law, Economics, and Organization 28.3 (2012), pp. 460-485.

Djankov, Simeon et al. "Courts". In: The Quarterly fournal of Economics 118.2 (May 2003), pp. 453-517.

Ghosh, Sayan. "Debt recovery tribunals fail to clear cases on time; outstanding debts stand at Rs 4,50,000 crore”. In: The Financial Express (May 17, 2016).

Hay, Jonathan R. and Andrei Shleifer. "Private Enforcement of Public Laws: A Theory of Legal Reform”. In: The American Economic Review 88.2 (May 1998): Papers and Proceedings of the Hundred and Tenth Annual Meeting of the American Economic Association, pp. 398-403.

Hobbes, Thomas. OfMan, Being the First Part of Leviathan. The Harvard Classics. Bartleby.com, 2001.

Home Affairs, Ministry of. Committee on Reforms of the Criminal Fustice System. 2003.

India Development Foundation. Fudicial Impact Assessment: An Approach Paper. May 2008. 
Jaiswal, Binita. "India needs more than 70,000 judges to clear pending cases". In: The Times of India (May 8, 2016).

Khaitan, Nitika, Shalini Seetharam, and Sumathi Chandrashekaran. Inefficiency and Judicial Delay. New Insights from the Delhi High Court. Vidhi Centre for Legal Policy, 2017.

Law Commission of India. Report No. 245. Arrears and Backlog: Creating Additional fudicial (wo)manpower. 2014.

- Report No. 77. Delay and Arrears in Trial Courts. 1978.

Ministry of Finance. "Debts Recovery Tribunal (Procedure) Rules, 1993”. In: Gazette of India, Extraordinary G.S.R. 564 (E) (Aug. 20, 1993).

Nair, Remya. "Debt recovery tribunals' overhaul on the cards to tackle pendency”. In: Live Mint (Dec. 24, 2015).

National Mission for Delivery of Justice and Legal Reform. Towards Timely Delivery of Fustice to All: A Blueprint for Fudicial Reforms. Sept. 2009.

"Recovery of Debts Due to Banks and Financial Institutions Act". In: Text of Central Acts 51 of 1993 (1993), pp. 299-312.

Regy, Prasanth, Shubho Roy, and Renuka Sane. "Understanding judicial delays in India: Evidence from Debt Recovery Tribunals”. In: Ajay Shah's Blog (May 16, 2016).

Reserve Bank of India. Quarterly Statistics on Deposits and Credit of Scheduled Commercial Banks: December 2016. 2017.

Resolutions Adopted in the Chief Justices' Conference, 2016. Apr. 23, 2016.

"Securitisation and Reconstruction of Financial Assests and Enforcement of Security Interest Act”. In: Text of Central Acts 54 of 2002 (2002), pp. 327-345.

Supreme Court of India. Indian Fudiciary: Annual Report 2015-2016. 2016.

Unny, Mukund P. A Study on the Effectiveness of Remedies Available For Banks in a Debt Recovery Tribunal: A Case Study on Ernakulam DRT. CPPR Working Papers. Feb. 2011.

World Bank. Ease of Doing Business Report 2016. Measuring Business Regulations. online resource. Oct. 27, 2015.

- Ease of Doing Business Report 2016. Enforcing Contracts Methodology. 2016. 


\section{MORE BY THE AUTHORS}

- Regy P., (2017). Judicial Procedures will make or break the Insolvency and Bankruptcy Code, Blog. (February).

- Roy S., (2016). Run on Real Estate Companies, Blog. (November).

\author{
Prasanth Regy, \\ is Consultant, NIPFP \\ Email: prasanth.regy@nipfp.org.in
}

Shubho Roy,

is Legal Consultant, NIPFP

Email: shubho.roy@nipfp.org.in

\section{MORE IN THE SERIES}

- Parsheera S., Shah A., and Bose A., (2017). Competition Issues in India's Online Economy, WP No. 194 (April).

- Chakravartti P., and Mundle S., (2017). An Automatic Leading Indicator Based Growth Forecast for 2016-17 and The Outlook Beyond, WP No. 193 (March).

- Datta P., Malhotra S., and Tyagi S., (2017). Judicial Reviews and Money Bills, WP No. 192 (March).

National Institute of Public Finance and Policy,

18/2, Satsang Vihar Marg, Special Institutional Area (Near JNU),

New Delhi 110067

Tel. No. 26569303, 26569780, 26569784

Fax: 91-11-26852548

www.nipfp.org.in 